\title{
World War II Criminals in Belarusian Internet Mass-Media: The Cases of Anthony Sawoniuk and Vladimir Katriuk
}

\author{
BY \\ VERANIKA LAPUTSKA ${ }^{1}$
}

Jews have been an important component of multicultural society on the territory of Belarus for many centuries (see Appendix 1 showing the ethnic makeup of Belarus in 1897). At the beginning of the $20^{\text {th }}$ century, they were also becoming increasingly involved in politics, forming several specifically Jewish parties and becoming members of many other emerging political parties in the Russian empire. After the Bolshevik revolution, they continued to play an important role in the development of Belarusian culture and science. According to data from the Jewish Community in Belarus, 407,000 Jews lived on Belarusian territory in 1926 (Evreiskaia obschina v Resublike Belarus', 2004).

The 1939 Soviet census recorded 375,092 Jews living on the territory of Soviet Belarus before its unification with Western Belarus (Vsesoiuznaia perepis' naseleniia 1939). A Polish census from 1931 reported that 283,300 Jews were living in Western Belarus, then part of Poland (Katljarchuk 2013, p. 13). Overall, around 658,400 Jews inhabited Soviet Belarusian territories by June 1941 when Nazi Germany attacked the Soviet Union. Later, this figure would increase by thousands, as up to 820,000 Jewish migrants from occupied Poland poured over the border (Katljarchuk 2013, p. 13). The vast majority of them were killed during $1941-1945$ as a result of the Holocaust. No more than $10-12 \%$ of the Jewish population in Western Belarus and 50\% in Central or Eastern Belarus survived World War II; overall, approximately 800,000 Jews were liquidated on the territory of occupied Belarus (Rudling 2013b, p. 121). In fact, the USSR census of 1959 stated that only 150,084 Jews were living in Belarus at that time (Vsesoiuznaia perepis' naseleniia 1959).

\footnotetext{
The author expresses her deep gratitude to Dist. Prof. David R. Marples and Prof. Annamaria OrlaBukowska for their valuable assistance and advice on the research; Aliaksandr Herasimenka for his help on acquiring information from the British Library; Prof. Yaraslau Kryvoi and three anonymous peer-reviewers for their helpful comments and suggestions.
} 
Not only did the Holocaust physically eliminate Jews from the territory of Belarus, it also seems to have erased their presence from the collective memory of the Soviet population. Thus, in its public rhetoric, the Soviet Union usually sublimated 'the genocide of Jews within the massive overall human losses suffered by all peoples' of the USSR during World War II (Dean 2010, p. 267). Research devoted to the Holocaust was a 'taboo' topic for Soviet scholarship until 1988 (Rudling 2013a, p. 61), and school textbooks began referring to this terrible episode of human history only in the late era of the Soviet Union².

Attitudes towards this issue have not changed greatly since Belarus gained its independence. The cult of the 'Great Patriotic War' and the heroism of Belarusian partisans are key elements of official state propaganda, whereas the Holocaust is very much neglected by Belarusian authorities, who are wary that competing narratives could overshadow their main nation-building myth. The Belarusian state tries not to attract too much attention to the small Jewish community existing on its territory today, although gradual positive changes are taking place.

Thus, several Jewish cultural and historical museums do exist in Belarus, some synagogues are being renovated, and many monuments to the Jewish victims of World War II have been erected in Belarusian towns and cities with the support of the state (Katljarchuk 2013, pp. 16-17)3. However, according to the Simon Wiesenthal Center, Belarus remains one of the least active countries in investigating former Nazi executioners who murdered Jews on Belarusian territory; it is constantly ranked ' $\mathrm{X}$ ', for countries that fail to provide pertinent data on Nazi war criminals (Wiesenthal Center Annual Report 2013 and Wiesenthal Center Annual Report 2014). As a result, Belarusian public discourse is not very active in publicly discussing the Holocaust or the activities of Nazi collaborators who participated in the 'Final Solution' on Belarusian territory.

The aim of this paper is to describe the Belarusian Internet mass-media discourses surrounding the cases of two Nazi World War II criminals: Anthony Sawoniuk (who changed his name from Andrei when he moved to the United Kingdom) and Vladimir Katriuk. Anthony Sawoniuk, a citizen of the United Kingdom, was born in the Belarusian town of Damačava (or Domachevo in Russian transliteration), where he allegedly participated in the massacre of the local Jewish population.

\footnotetext{
For more on Holocaust memory politics in the BSSR and then in Belarus since 1991 see A. Katljarchuk, 'World War II Memory Politics: Jewish, Polish and Roma Minorities of Belarus', The Journal of Belarusian Studies, 2013:1, pp. 14 - 18; P.A. Rudling, 'The Invisible Genocide: The Holocaust in Belarus', in Bringing the Dark Past to Light, ed. J. - P. Himka and J. B. Michlic, University of Nebraska Press, 2013, pp. 59 - 82; P. A. Rudling, 'Neprykmietny hienacyd: Chalakost u Bielarusi'. ARCHE 2, July 2013, pp. $124-138$.

3 Nevertheless, only one wall in hall number 6 of the Museum of the History of the Great Patriotic War in Minsk is devoted to the Holocaust, and the total number of Jews killed on Belarusian territory is not specified, only the overall figure of civilians and prisoners of war murdered in Belarus during 1941 - 1945. The author visited the Museum on July 28, 2015.
} 
He was prosecuted in London and found guilty. Vladimir Katriuk, a Ukrainianborn citizen of Canada, was a soldier in the Schutzmannschaft Bataillon 118 during WWII. During his time as a soldier, he allegedly perpetrated numerous atrocities on Belarusian territory (Rudling 2012, p. 42), including the Chatyń (Khatyn) massacre, where 149 Belarusians were killed.

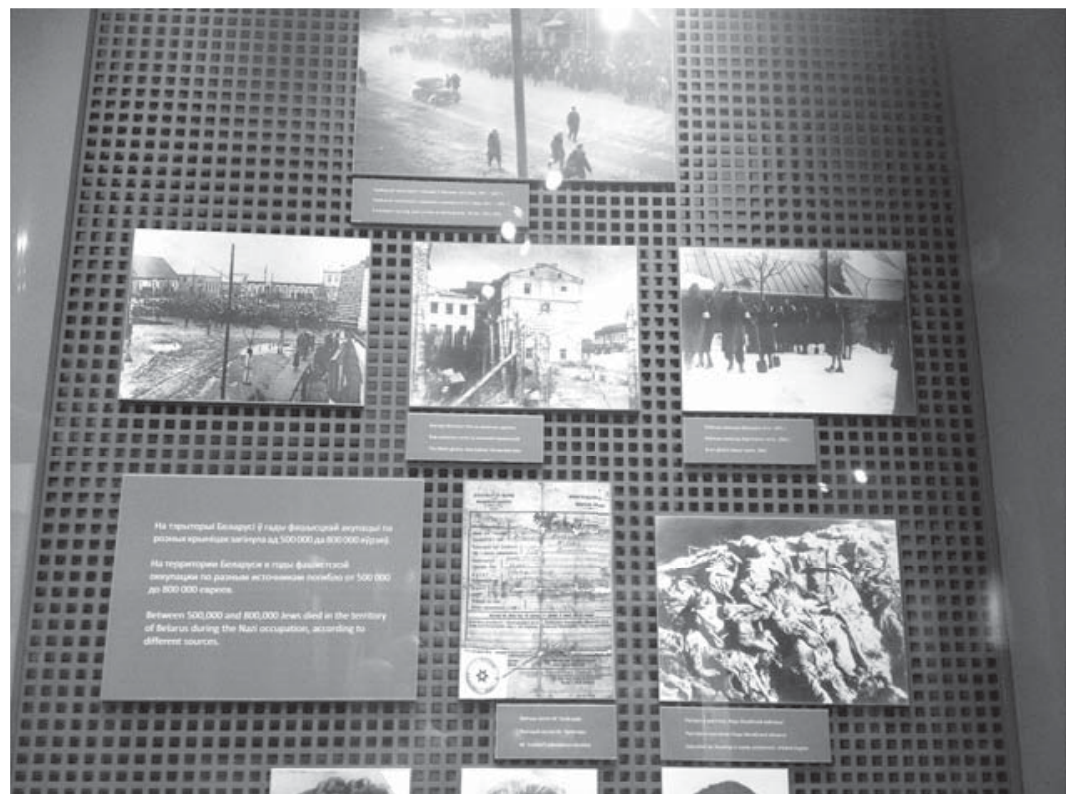

FIGURE 1: The Belarusian Museum of the Great Patriotic War.

One of three stands devoted to the Holocaust in Belarus containing images from Minsk and Viciebsk ghetto and a photo of victims killed in Viciebsk region. Center-left inscription mentions a total number of Jews killed on the Belarusian territory during Nazi occupation - between 500,000 and 800,000 people.

Photo taken by Veranika Laputska on 28 July 2015

This paper is forced to use the term 'allegedly': despite the fact the Federal Court of Canada, during his denaturalization trail, established that as a member of Battalion $118 \mathrm{Mr}$ Katriuk '[had taken part] in the operations in which his company was involved, and, as a result, was certainly engaged in fighting enemy partisans', Katrituk did not divulge that information when he immigrated to Canada. As a result, officially 'all deportation procedures were stopped in 2007 due to the lack of evidence'. Moreover, Mr Katriuk has never been tried solely for the Chatyń massacre.

Chatyń remains one of the most infamous tragedies to occur on Belarusian territory during World War II. It has become a symbol not only of Belarusian but also Soviet tragedy and grief caused by the Nazis (Chatyń Memorial Complex 2005 
and Rudling 2012, pp. 29-58). After the war, the massacre was commemorated with a memorial complex located on the site of the former village of Chatyń near Minsk.

This paper aims to explore these two specific cases and compare their coverage in the Belarusian Internet mass-media, keeping in mind that in one case Belarusian Jews were massacred by an ethnic Belarusian, whereas in the second ethnic Belarusians were massacred by a non-Belarusian Nazi collaborator. The reason for investigating these cases in particular is the fact that both men were tried relatively recently (that is, the late 1990s - 2010s).

The article analyses the discourse among different groups of Belarusian Internet mass-media. Due to the overlap between the Russian and Belarusian Internet mass-media space, the paper also examines several Russian publications which have influenced information in the Belarusian media space. The study focuses on publications in three groups of web-sites:

1) state-owned and pro-government Internet mass-media. Such publications propagate the official opinions of the Belarusian authorities. This category includes the web-sites of the following Belarusian newspapers: Belarus SegodniaSovetskaya Belorussiya, Respublika, Zviazda, Narodnaja Hazieta, Belorusskaya Niva, etc.;

2) pro-democratic mass-media. These do not share the official views of the Belarusian state. They promote democratic values in Belarus and advocate freedom of speech. They include: Radio Free Europe/Radio Liberty (www.svaboda.org), Belarusian Partisan (www.belaruspartisan.org); European Radio for Belarus (euroradio.fm), Naša Niva (www.nn.by), Charter 97 (www.charter97.org) and Novy Čas (www.novychas.info), etc.;

3) 'neutral' mass-media. Publications in this category refrain from promoting state ideology but also distance themselves from the opposition, thus lacking a particular political agenda. Such media also maintain a neutral attitude toward the Belarusian regime. They include: the news portal Tut.by (www.tut.by), Vechernii Minsk (vminsk.by), and the portals naviny.by, udf.by, odsgomel.org and domachevo. com, etc.

The paper analysed the Internet publications which garnered the most hits in a Google search of the cases in both Russian and Belarusian languages. Some additional information was also acquired in English when necessary. Thus, this study does not imply a comprehensive coverage of every article written on Sawoniuk and Katriuk on the Internet. Moreover, certain potentially relevant pieces may have already disappeared from the Internet due to the specific features of certain web-sites. A vast majority of websites only keep a certain amount of data - mainly depending on their age - so older pieces may have been deleted even from the cache. 
Due to the fact that a well-elaborated methodology defining the political affiliation of Belarusian media outlets is missing, the author took the following criteria in mind when categorising Belarusian Internet mass-media according to the three groups described earlier: rhetoric and events described, language - Belarusian or Russian - where Belarusian media is more likely to be in opposition to the state, and the political and professional background of the journalists.

This paper consists of three parts. The first part describes the case of Anthony Sawoniuk and the subsequent reaction of Belarusian Internet mass-media both to the story itself and to the trial against him in London. The second part deals with the case of Vladimir Katriuk and academic and journalistic pieces written about him. It also explores the ways in which Belarusian and Russian media outlets presented Katriuk's story, as well as the interaction between Canada and the Russian Federation when the latter requested that Katriuk be extradited. The conclusion sums up the main discursive trends within each of the three groups of Internet mass-media and endeavours to explain the reasons behind the differences.

\section{Anthony (Andrei) Sawoniuk in Belarusian Internet Mass-Media}

As Anne Applebaum stated in her 1999 article 'The nightmarish world that awaits a British jury,' published during the trial against Anthony Sawoniuk, the 'current [Belarusian] government has no interest in investigating either the nation's Nazi or its Soviet past...' (Applebaum 1999). The very poor coverage by the Belarusian media of the first and only Nazi war criminal prosecuted and convicted under the 1991 War Crimes Act in the United Kingdom proved the relevance of this citation. Several witnesses claimed that Sawoniuk personally killed several Jewish men and women in Nazi-occupied Damačava, his native town. Sawoniuk never pled guilty, despite the fact that the trial resulted in Sawoniuk receiving two life sentences for the murder of 18 Jews in Damačava (The Guardian 2005).

In 1999, the Minsk regional newspaper Vechernii Minsk published only one small piece regarding this case, which appeared in conjunction with data from the Belarusian Telegraph Agency - BelTA (Kobiak 1999). The article reported on the British jury delegation's visit to Damačava to investigate Sawoniuk's crimes and talk to the handful of surviving witnesses. It also discussed the 'few dozen journalists from leading Western countries, information agencies, and television companies' (Kobiak 1999). Belarusians journalists refrained from actively covering the event.

A Radio Liberty/Radio Free Europe journalist from Brest, Aleh Supruniuk, wrote an article regarding the trial of Mr Sawoniuk - also in 1999 (Supruniuk 1999). The article covered the British jury delegation's visit to Damačava and the story of Sawoniuk's accusations in the UK court. 


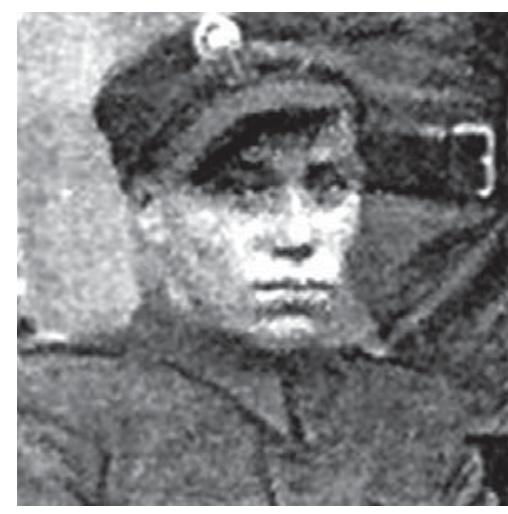

FIGURE 2: Sawoniuk young

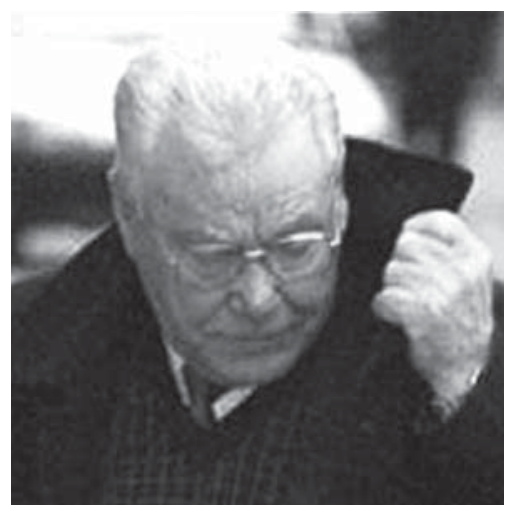

FIGURE 3: Sawoniuk old

Another Belarusian pro-democratic website, Naša Niva, also devoted an article to Sawoniuk's case in 1999. The author of the article, journalist Valier Kalinoŭski, visited Damačava himself. He spoke with local inhabitants who still remembered Sawoniuk's crimes and described the town and what the execution site of the local Jewish population looked like in 1999 (Kalinoŭski 1999).

The website of the Institute of Human Rights in Moscow, www.hrights.ru, whose contributors include Belarusian historian and opposition activist Valiancin Holubieŭ, also mentioned the visit of the London court delegation to Brest and Damačava on 15-17 February 1999. The article was placed in a section covering Belarusian history and political and diplomatic relations between the Republic of Belarus and other countries. More precisely, it was in the section covering relations between the UK and Belarus (Holubieŭ 1999). The publication pointed out that one of the reasons why Sawoniuk was not eligible for extradition to Belarus, the country where he was believed to have committed war crimes, was that the norms of the European Union's justice system forbid sending suspects to countries still practicing the death penalty.

Another series of articles devoted to Sawoniuk appeared after his death in a British prison in 2005. This time, not only the main opposition websites, such as svaboda.org, covered the story (Svaboda 2005), but so did the main state newspaper Sovetskaia Belorussiia (Krapivin, 2005). In a style very typical of state owned mass-media, which involves the use of slang expressions such as 'na zone' (English in the zone meaning in jail) or 'to give your soul to Devil' (as a description of Sawoniuk's death) (Krapivin 2005), the article explored the story of Sawoniuk's collaboration with the Nazis and his trial in the UK. This was the first time that an article regarding Anthony Sawoniuk appeared in a major Belarusian newspaper. Notably, the author comments that Sawoniuk's real name, Andrei, was discovered the day before the article was written with the help of the Belarusian KGB. 
A more detailed article by V. V. Datsyk about Sawoniuk appeared on the home page of his native town Damačava - domachevo.com, although it was probably uploaded later than his 1999 visit, as the website only began functioning in 2006 (Datsyk 2006). The article provides Sawoniuk's biography, confirming that he was born in Damačava and participated in the executions of people from his native town. It also contains several photographs, including one taken of the British jury delegation visiting Damačava. The author himself points out that he gathered the material from Wikipedia but also used several articles by British journalists published in 1999 in The Independent and The Guardian (Datsyk 2006).

Several Belarusian media outlets recalled Anthony (Andrei) Sawoniuk in 2010 when the Simon Wiesenthal Center placed another Nazi collaborator, Mikhail Gorshkow, on a list of the ten most wanted Nazi war criminals. Gorshkow was responsible for the murder of Jews in Sluck (Slutsk). The most popular Belarusian news portal - tut.by - described Sawoniuk in one article as 'the Damačava animal', due to his remarkable cruelty (Lashkevich 2010). The article listed five other Nazi war criminals persecuted in different countries for crimes committed on Belarusian territories during World War II.

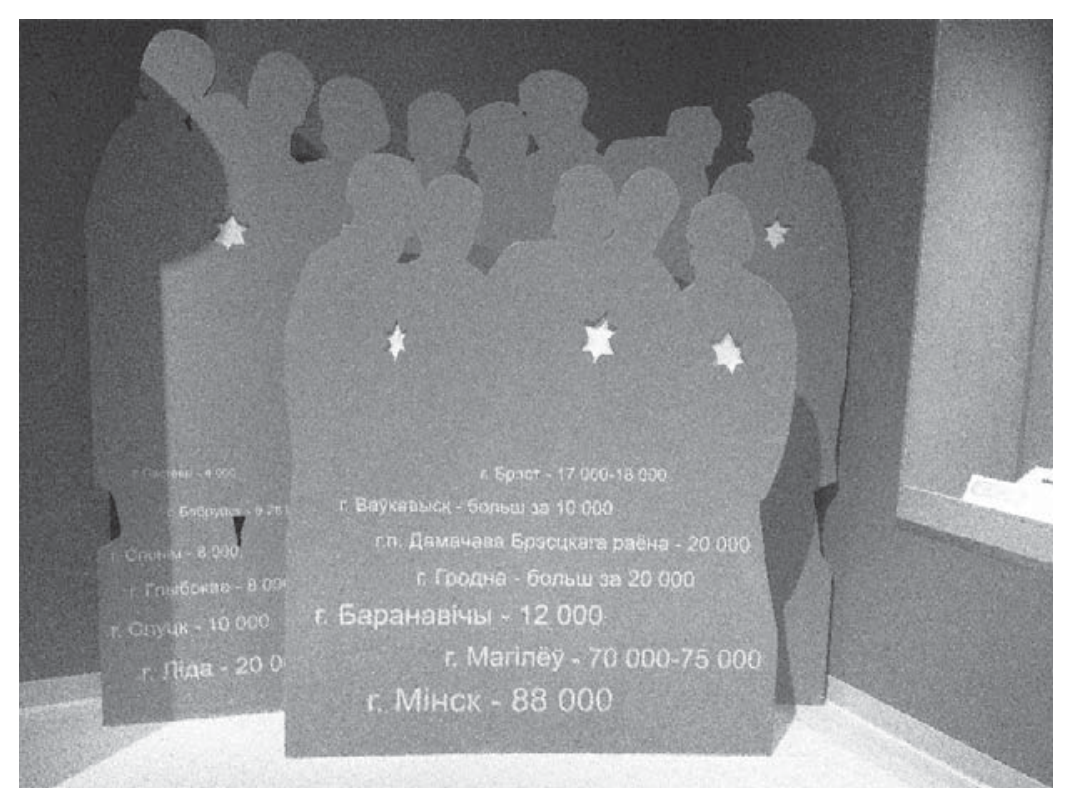

FIGURE 4: The Belarusian Museum of the Great Patriotic War. Installation devoted to Jewish victims of the World War II in Belarus. The third line in the center states a number of Jews killed in Damačava in Brest region - 20,000.

Photo taken by Veranika Laputska on 28 July 2015 
The fact that it was mainly 'neutral' and pro-democratic newspapers which published articles about Anthony Sawoniuk during his prosecution shows how little importance the Belarusian authorities placed on the topic of the Holocaust at that time. Despite the uniqueness of the trial against Sawoniuk, both for that particular time and for the judicial system of the United Kingdom, the Belarusian official media ignored the subject. The main state newspapers covered Sawoniuk's story only in 2005, when he died in a British jail in Norwich. Later on, his name re-emerged in the media after the discovery of other Nazi war criminals engaged in murders on Belarusian territory.

\section{Vladimir Katriuk in Belarusian Internet Mass-Media}

Vladimir Katriuk was born in 1921 in the village of Luzhany near the city of Chernivtsi in Ukraine (Canada (Minister of Citizenship and Immigration) v. Katriuk 1999). After the start of the war between the Soviet Union and Nazi Germany, the latter organised two military formations out of the Organization of Ukrainian Nationalists (OUN): the Bandera wing (OUN(b)) and the Melnyk wing (OUN(m)). The Melnyk wing formed a 900-member Bukovinian Battalion (Bukovyns'kyi Kurin') and marched into Ukraine in summer 1941 (Rudling 2012, p. 34).

Katriuk was part of the Bukovinian Battalion and later the Schutzmannschaft Batallion 118. As a member of Batallion 118, Vladimir Katriuk fought in Ukraine, Belarus, East Prussia, and France. There he managed to join the French Foreign Legion, which he later deserted. Katriuk was able to acquire fake documents and stayed in France until August 1951, when he and his wife arrived in Quebec City under the name Schpirka after having obtained Canadian visas. Vladimir Katriuk did not tell the Canadian Consulate what he had been doing between 1938 and 1945. In 1957, both he and his wife changed their names to Katriuk and in 1958 they applied for Canadian Citizenship (Canada (Minister of Citizenship and Immigration) v. Katriuk, 1999).

Katriuk's name presumably came to light during the Deschenes Commission hearings in 1985-86. In the early 1980s, the Soviet KGB visited Katriuk's relatives in Ukraine; they later requested more information on him during the Gorbachev era. On 15 August 1996 Mrs and Mr Katriuk received a letter from the Ministry of Citizenship and Migration revoking their citizenship (Canada (Minister of Citizenship and Immigration) v. Katriuk 1999). In 1999, the Federal Court of Canada established that Mr Katriuk had gained access to Canada by providing false information. Nevertheless, denaturalization and deportation procedures were suspended in 2007 'due to lack of evidence' (Rudling 2012, p. 42). 


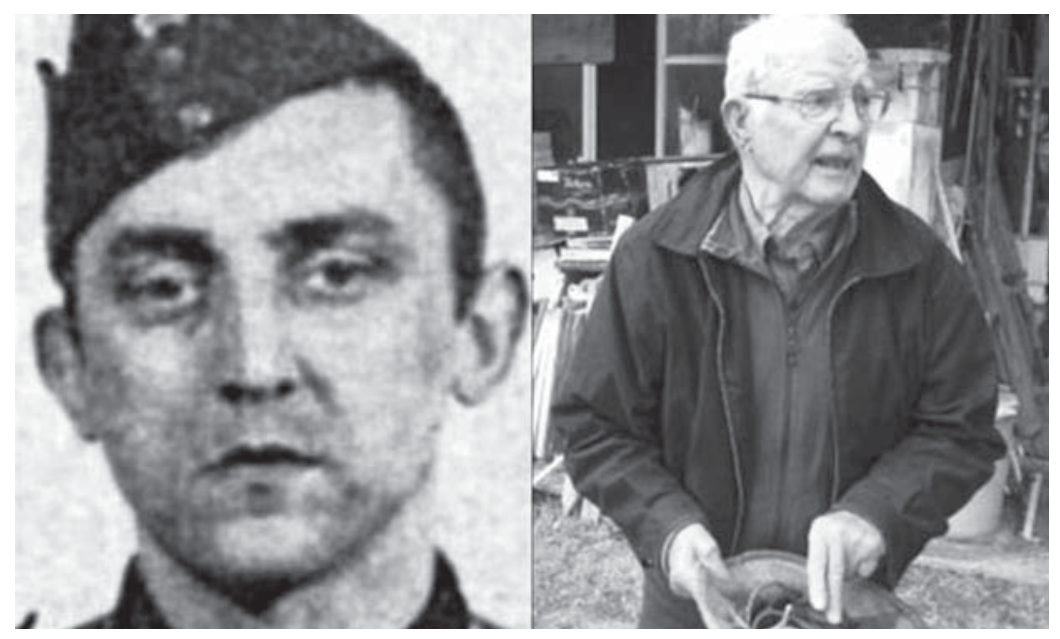

FIGURE 5: Katriuk

The crimes of Vladimir Katriuk, which placed him third among the most wanted Nazi war criminals according to the Wiesenthal Center's 2014 annual report (Wiesenthal Center Annual Report 2014), re-emerged thanks to Swedish historian Per Anders Rudling (Rudling 2011, pp. 195 - 214). The name of Vladimir Katriuk had been mentioned previously during trials against Vasyl Meleshko ${ }^{4}$ and Hryhoryi Vasiura, other members of Schutzmannschaft Batallion 118, in 1975 and 1986 respectively (Rudling 2012, pp. 38 -40). Both men were sentenced to capital punishment in a Soviet court. Vladimir Katriuk was never sued for his crimes (including the slaughter of the inhabitants of Chatyń in 1943) and died in Canada in 2015 .

Chatyń was one of the numerous Belarusian towns and villages which was burned down, often along with their inhabitants, by the Nazis and their collaborators during World War II. Christian Gerlach states in his book Kalkulierte Morde: Die deutsche Wirtschafts- und Vernichtungspolitik in Weißrußland that massacres connected with the 'war against peasants' took place in 5,295 different locations in Belarus (Gerlach 1999, p. 943). Gerlach's analysis of Romanowski's statistics indicated that $3 \%$ of these cases happened in $1941,16 \%$ in 1942 , and $18 \%$ in 1944, and no less than $63 \%$ in 1943, when Chatyń's inhabitants were also massacred (Gerlach 1999, p. 943). The first half of 1943 coincided with the time when the Nazis had elaborated the notorious concept of 'dead zones' (Gerlach 1999, p. 1011).

\footnotetext{
4 For more about Vasyl Meleshko see here: S.S. Maksimov, Istoriia odnogo predatelstva, Neotvratimoie vozmezdiie: Po materialam sudebnykh protsessov nad izmennikami Rodiny, fashistkimi palachami $i$ agentami imperialisticheskich razvedok, Moskva, 1979, 294 p. Voyennaya literatura. Available at: $<\mathrm{http} / / /$ militera.lib.ru/h/sb_neotvratimoe_vozmezdie/12.html >. [Accessed 06.03.2016].

5 For more on various operations during that period in Belarus see Gerlach, 1999, pp. 1010 - 1036.
} 


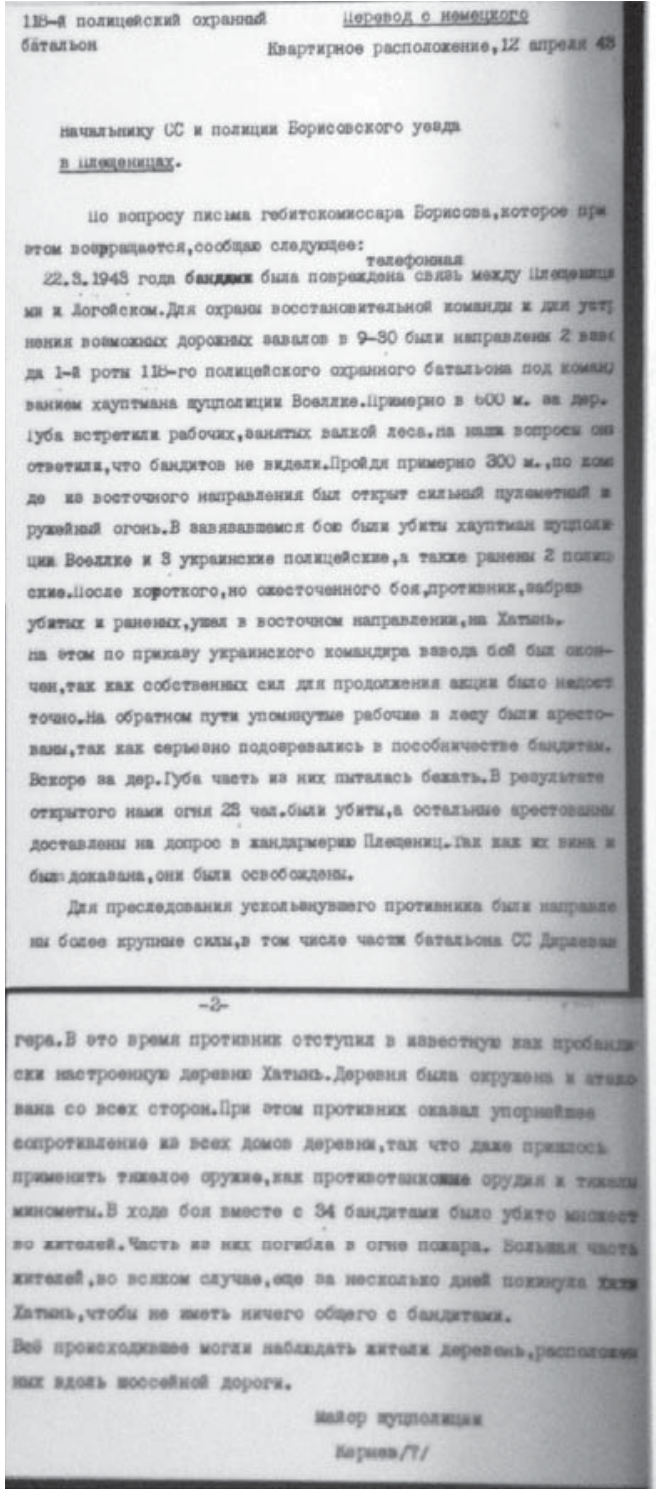

FIGURE 6: Chatyń museum. A photo of the report by Schutzmannschaft Bataillon 118 about Chatyń massacre translated into Russian. The document mentions participation of Ukrainian collaborators in activities of Schutzmannschaft Bataillon 118. Photo taken by Veranika Laputska on 29 July 2015 


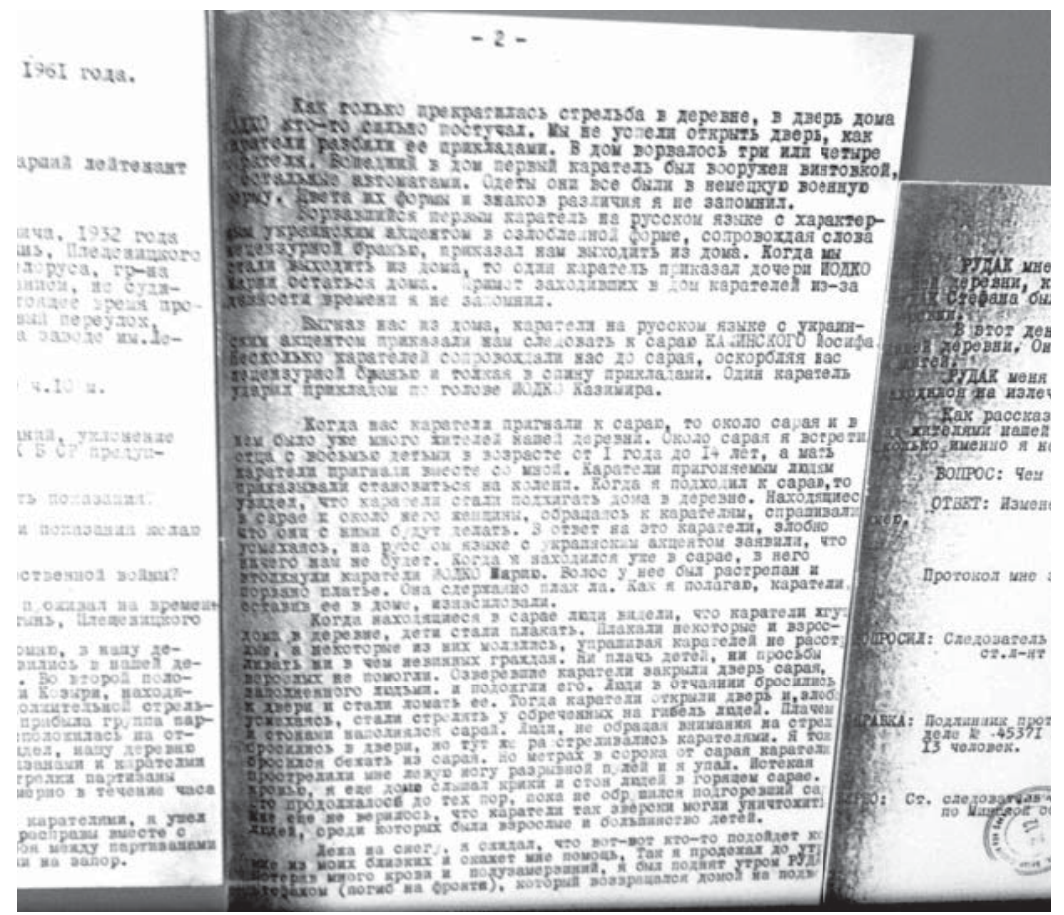

FIGURE 7: Chatyń museum. Evidence given by Anton Baranoúski on 28 April 1961 confirming palicai executed Chatyń inhabitants spoke Russian with a strong Ukrainian ascent. Anton Baranoúski witnessed the Chatyń massacre. Photo taken by Veranika

Laputska on 29 July 2015

The Chatyń memorial became an important place for the commemoration of tragedies inflicted upon the Belarusian population during the war. BSSR officials opened the memorial complex in 1969 not far from Lahojsk in Minsk region. Since then, it has attracted tourists from many different countries ${ }^{6}$. Remarkably, the website of the memorial, which tells the story of the tragedy and describes the place of the Belarusian territories in Nazi policies, does not have a sub-section entitled 'Genocide of the Jews' or 'Genocide of the Roma', Poles $^{8}$ or any other nationality also present in Belarus at the start of World War II.

The scale of their losses was also not reflected or mentioned on the territory of the monument itself (Katljarchuk 2013, p. 11). Instead, the website had a section entitled 'Genocide Policy,' whose sole sub-section was 'the Genocide of the Belarusian

6 NB: during a short interview with Memorial's employees conducted by the author on 29 July 2015 they said that they were aware of Vladimir Katriuk's story. However, they added they try not to mention too many executors in their oral and written narrative of the tragedy and skip using their last names in order to not to glorify them. Instead guides try to tell the stories of those who survived. This should be the core of the story in their opinion.

7 For more on the Roma Genocide see Katljarchuk, 2013, pp. 18 - 23.

8 For more on the Genocide of the Polish minority, its history and politics in Belarus see Ibidem, pp. 23 - 29. 
people', although according to international law the mass murders of the Belarusian civil population cannot be classified as genocide (Katljarchuk 2013, pp. 12 -13).

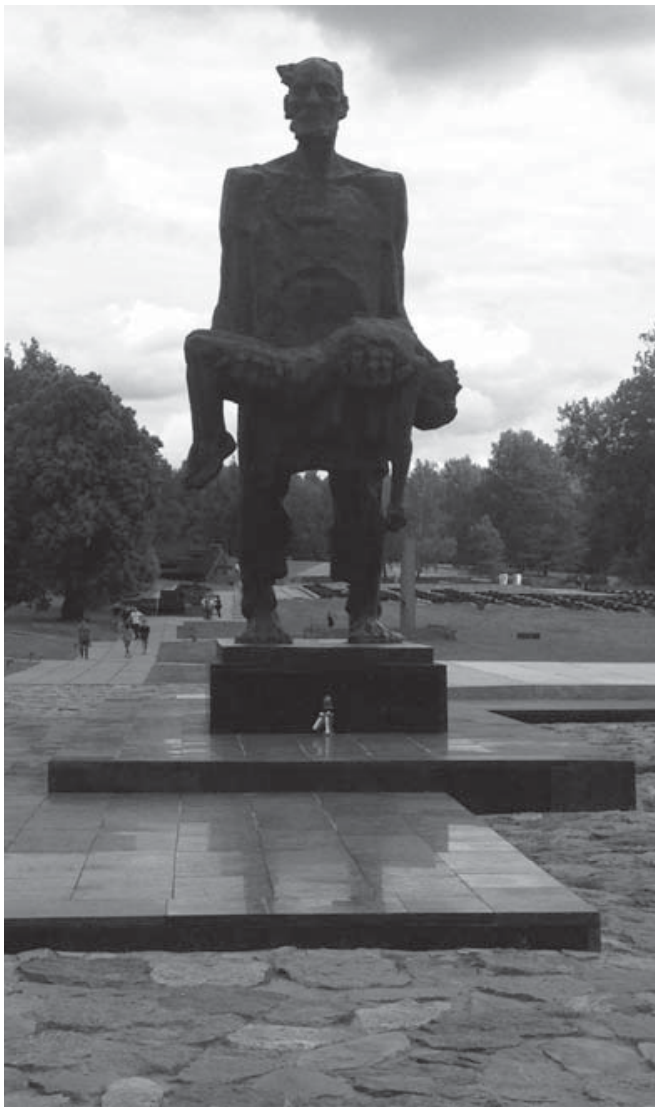

FIGURE 8: Chatyń memorial. An iconic photo of Chatyń sculpture of the Unconquered Man by S. Sielivanaú. It was based on survivor of the tragedy Iosif Kaminski who lost his family in fire. Photo taken by Veranika Laputska on 29 July 2015

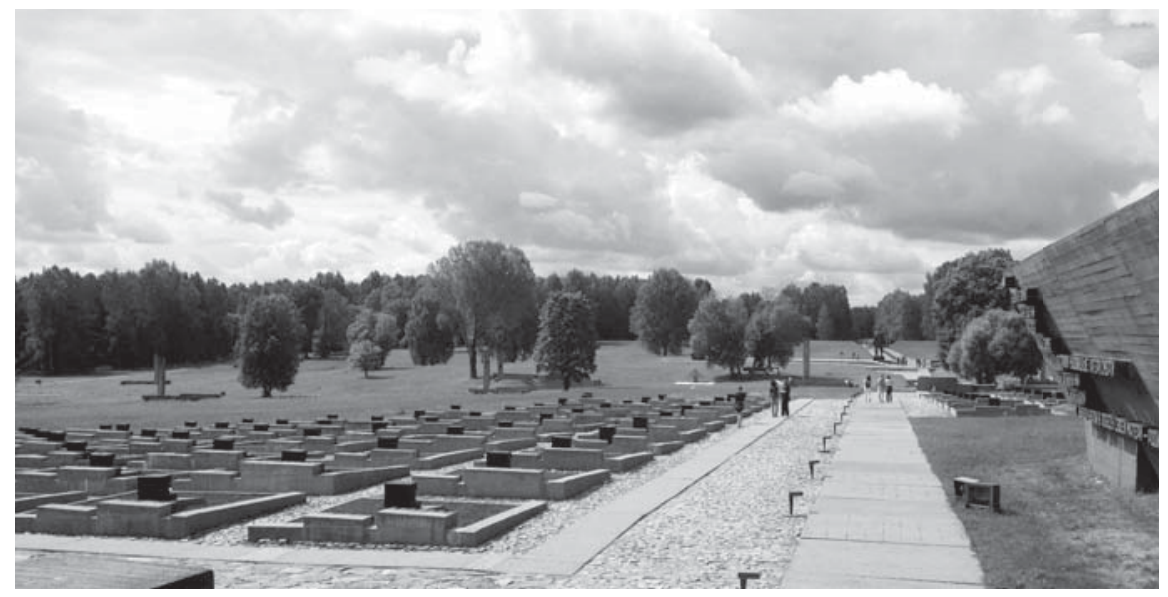

FIGURE 9: Chatyń memorial. View on "cementry of villages"and the main monument. Photo taken by Veranika Laputska on 29 July 2015 


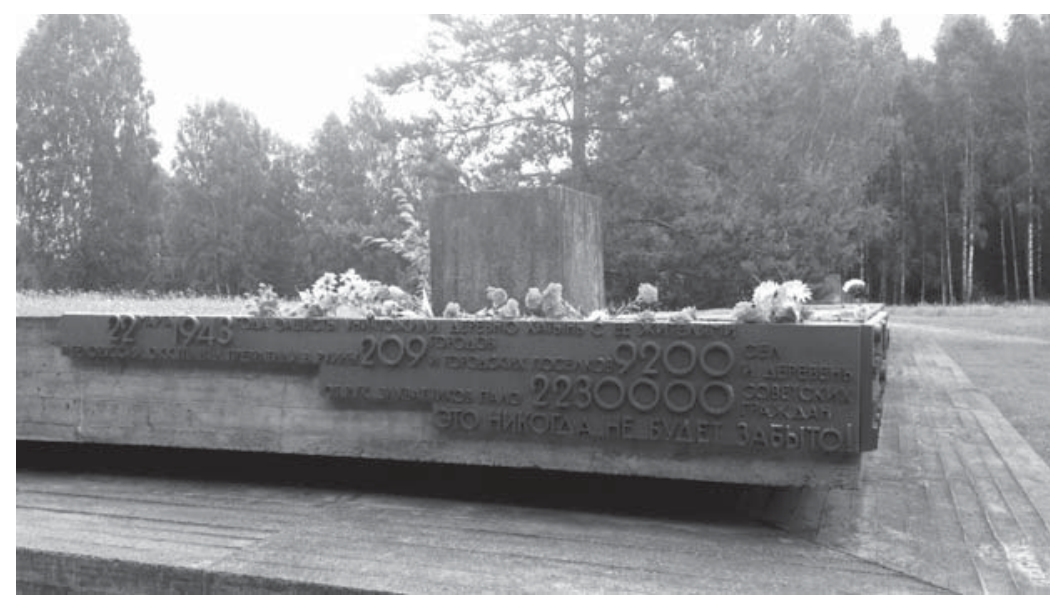

FIGURE 10: Chatyń memorial. A monument stating how many Belarusians died in 1941 - 1945 and how many villages, towns and cities were destroyed.

Photo taken by Veranika Laputska on 29 July 2015

Notably, even though Per Anders Rudling's article clearly stated the involvement of the Schutzmannschaft Batallion 118 in the extermination of the Jews on the territories under its control, this part of Katriuk's biography was not covered by the vast majority of Belarusian mass-media Internet publications. In contrast, the mass-media from all three groups studied in this paper touched upon Vladimir Katriuk's involvement in the Chatyń tragedy.

Thus, Respublika, the second largest state-owned Belarusian newspaper (after Sovetskaia Belorussiia) published an article in April 2012 devoted to Vladimir Katriuk's discovery in Canada (Respublika 2012). It described testimonies from other members of the Schutzmannschaft Bataillon 118, revealing the details of the Chatyń massacre using quite aggressive vocabulary.

Several news portals also covered this story. For instance, an article regarding Katriuk's discovery appeared on the news portal Naviny.by (Naviny 2012). The Udf.by news web-site published a similar article with a less neutral title (Udf.by 2012). In contrast to Respublika and Naviny.by, it avoided using words such as 'butcher'. A Homieĺ regional news web-site, odsgomel.org, also devoted some space to news about one of the Chatyń executioners (Silnye novosti 2012).

Most opposition websites also mentioned Vladimir Katriuk's case in their publications. Naša Niva reprinted a news item from the news agency Interfax.by (Naša Niva 2012), as did the Belarusian Partisan web-site, which also published a story about Katriuk and Chatyń (Belaruspartisan 2012). European Radio for Belarus also devoted some space on their web-page to the topic (European Radio for Belarus 2012). 
The story also attracted the attention of Belarus's neighbour Russia. One of the most important state channels - NTV - reported on Vladimir Katriuk from Canada in April 2012. Remarkably, the journalists pointed out that much attention was paid to the Chatyn massacre during the Soviet era in order to distract the world from the Katyn tragedy (NTV 2012). In 2015, in view of the conflict between Russia and Ukraine, it would be very unlikely for a Russian reportage to makes this claim, as Russian propaganda is becoming more and more similar to Soviet reporting.

The story of the Chatyn massacre remains very important for the Belarusian public. Therefore, several more pieces worth mentioning have emerged on the Belarusian Internet since Vladimir Katriuk's story first broke. For example, in October 2013 the Belarusian state newspaper Zviazda published an article devoted to Schutzmannschaft Battalion 118 citing its other crimes, including the murder of Jewish families in Hrodna region in 1943 (Dalidovič and Marozava 2013). Hrodna University professor Sviatlana Marozava wrote the article together with Jauhien Dalidovič, a veteran of World War II and a former criminal investigator for the KGB in Hrodna region. The article mentioned that in many cases, in-depth research on Nazi crimes on Belarusian territory remains unlikely until the Belarusian KGB make secret files available to academics. At the moment, the self-induced isolation of the current Belarusian government, along with the lack of transparency and even secrecy of many of its institutions hamper scholarly activity in this field.

On 28 March 2014, a documentary film entitled The Shameful Mystery of Khatyn, filmed in 2008, was uploaded to Youtube.com. Interestingly, a note at the very end of the film states that it was made by a company named 'Super Reality' upon the request of the Joint Broadcasting System of the Russian Armed Forces.

At 22 minutes, the narrator shares the story of Vladimir Katriuk and his participation in the Chatyń massacre (Dykhovichnaia and Moloslavov 2008). What follows is a video shot during demonstrations by former members of the Ukrainian Insurgent Army and the Organisation of Ukrainian Nationalists (UIA/ OUN) in contemporary Ukraine. This is accompanied by the narrator's commentary on current Ukrainian memory politics. At minute 26, the narrator arrives at the Belarusian KGB special archive and enquires about Katriuk again (Dykhovichnaia and Moloslavov 2008). At minute 35, he reveals that Katriuk is an honorary citizen of Chernivtsi and shows several interviews with Chernivsti historians claiming that Schutzmannschaft Batallion 118 did not commit any crimes on Belarusian territory (Dykhovichnaia and Moloslavov 2008). At the end of the film, the narrator suggests that there might be other former members of Schutzmannschaft Batallion 118 still living in Ukraine.

The documentary clearly condemns not only members of Schutzmannschaft Bataillon 118, but also the Ukrainian memory politics adopted after the Orange Revolution. Remarkably, the film was uploaded on youtube.com in March 2014, in 
the midst of the Revolution of Dignity in Ukraine. The comments to the video have remained active in 2016 and contain hateful rhetoric against Ukrainians.

Novy Čas journalist Alieś Kirkievič conducted a sophisticated work of research in June 2014 which includes a digression into the history of Ukrainian collaborators and their activities on the Belarusian territories in World War II (Kirkievič 2014). He points out that this subject has become especially crucial for the Russian massmedia since the beginning of the Russian-Ukrainian conflict in 2014. According to him, Katriuk due to his origin ${ }^{9}$ would continue to be a hot topic for both Russian and Belarusian state media as long as the conflict in Ukraine remains unresolved.

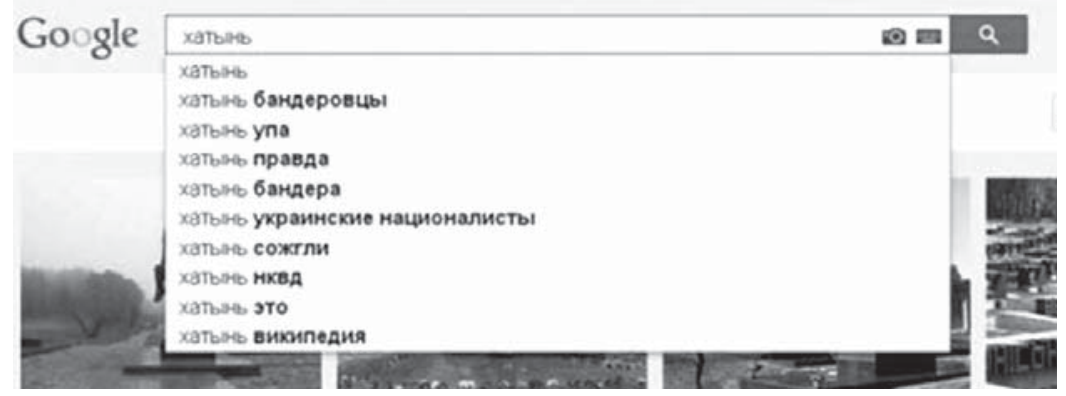

FIGURE 11: June 2014. Source: Kirkievič 2015. Khatyn: kto spaliu belaruskuyu viosku [online]. Novy chas. http://novychas.info/poviaz_casou/chatynj_zorstkaje_recha_histor/ accessed on 02.02 .2015

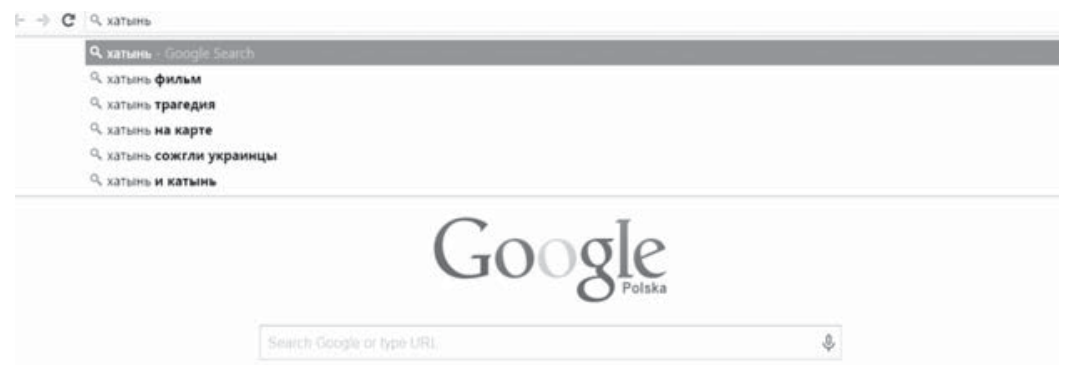

FIGURE 12: July 2015

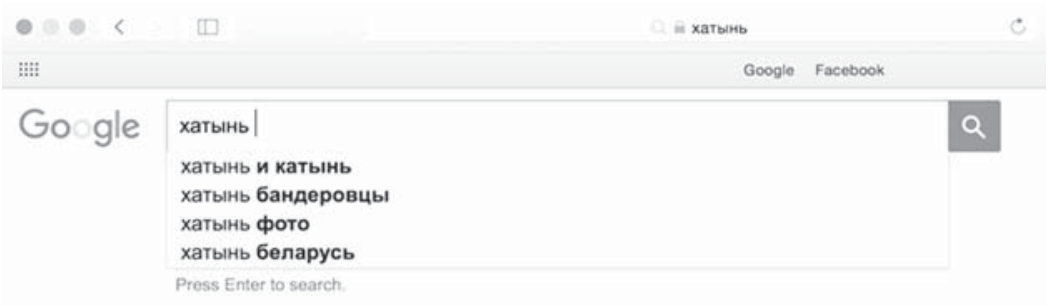

FIGURE 13: March 2016

9 NB: When Vladimir Katriuk's was born, in 1921, the place of his birth was in the Kingdom of Romania. 
This hypothesis has proven true. Already on 17 June 2014, a documentary film entitled Declassified History: Chatyn' 's Butchers, produced by the Russian television channel Rossiya - Kultura (Russia - Culture) appeared on several popular video portals. The video, uploaded to youtube.com, had only comment- about Vladimir Katriuk's participation in the Chatyń massacre; Vladimir Katriuk was still alive at that time (Kuzovenkov 2014). None of the names of the rest of the 'butchers' appeared in the video description, even though there was only one reference to Katriuk in the entire film (Kuzovenkov 2014). The documentary film comprises part of a project called Declassified History and can be accessed together with other 'declassified' stories via the channel's webpage (Kuzovenkov 2014). The fact that Russian television (rather than Belarusian) decided to make a film about Chatyń and the people of Ukrainian origin who participated in the massacre there as late as 2014 remains suspicious, given Russian foreign policy towards Ukraine, as well as Ukraine's media image in Russia at the time.

Another wave of interest in Vladimir Katriuk emerged on 8 May 2015, when the Russian Federation - as the 'legal successor' of the USSR - requested the extradition of the Canadian citizen to Russia (Svoboda 2015). The Committee of Inquiry of the Russian Federation started a criminal case accusing Katriuk of genocide (Article 357 of the Criminal Code of the Russian Federation) (Vesti 2015). Notably, the Russian media called Vladimir Katriuk a 'murderer', even though legally a court had never found him guilty. On 27 May 2015, the Deputy Prosecutor-General in Russia, Alexander Zvyagintsev, stated that Canada had refused to extradite Katriuk (Subbotin 2015). On 29 May 2015, the Toronto Globe and Mail reported that Vladimir Katriuk had died in hospital on 22 May 2015 at the age of 93 (Tu Thanh Ha 2015).

On the very same day, the Russian newspaper Vzglyad published an article questioning whether Vladimir Katriuk had actually died, and compared his case to that of Ivan Demjanjuk ${ }^{10}$, who had also been ill during the last months of his trial for the murder of thousands of Jews in the Sobibor concentration camp (Baltacheva and Neroznikova 2015). Another Russian newspaper, MK - Moskovskiy Komsomolets, published an article about Katriuk's death citing 'trial materials' against Katriuk from 1999 (Rinaeva, 2015). Remarkably, the link to the materials turned out to be the live journal $^{11}$ account of a certain Andrei Svetlako from 2009 (Svetlako 2009). Svetlako claims to have translated the trial documents from English and provided links to the originals. However, at the time of writing, the original links showed no such documents, although original documents on the case can indeed be accessed on the Internet (for example, Canada (Minister of Citizenship and Immigration) v. Katriuk 1999).

\footnotetext{
${ }^{10}$ For more about the case of John Demjanjuk see L. Douglas, The Right Wrong Man: John Demjanjuk and the Last Great Nazi War Crimes Trial, Princeton University Press 2016, 352 p.

${ }^{11}$ Live journal is a free personal blog open to the public.
} 
Not only does the Belarusian Internet mass-media work closely with the Russian mass-media (because of their common language and media discourse), they are also prone to use similar language when describing Katriuk's death and life. For example, the main Belarusian state newspaper, Belarus Segodnia Sovetskaya Belorussiya, devoted a series of articles to Chatyń during May - June 2015. Certainly, it is possible to link this interest to the upcoming $70^{\text {th }}$ anniversary of the end of the Great Patriotic War' ${ }^{12}$, which was celebrated on 9 May 2015 and is one of the main contemporary state holidays in Belarus, along with another important date for state propaganda: 22 June (the anniversary of the beginning of the Great Patriotic War - the German invasion of the USSR). However, the fact that articles also appeared in the Russian media cannot be ignored. It is possible that the actions of the Russian Committee of Inquiry forced the Belarusian mass-media to pay additional attention to the story of the Chatyń massacre.

On 6 May 2015, an affiliated newspaper of Belarus Segodnia - Sovetskaia Belorussiia, Narodnaja Hazieta (People's Newspaper), published an interview with the historian Viačaslaŭ Seliameniaŭ, Head of the National Archives of Belarus, who had studied and published on Chatyń (Moskalenko 2015). Seliameniaŭ mentioned Katriuk in his interview and expressed his dismay that the man was still free (Moskalenko 2015).

On 10 May 2015, Belarus Segodnia - Sovetskaia Belorussiia published an article about the Russian Committee of Inquiry's request to extradite Vladimir Katriuk (Nosov 2015). Another article on the same topic appeared in the newspaper on 29 May 2015. The article, by one Roman Rud', condemned Canada for refusing to extradite Katriuk to Russia and used highly propagandistic language to describe the 'cynicism' of the Canadian judicial system, also mentioning Katriuk's name in connection with the Ukrainian Insurgent Army (UIA) (Rud' 2015b), although Katriuk had never been part of the UIA. The article was followed by a postscript stating that Vladimir Katriuk had died after the article was initially published in the paper version of the newspaper.

The same author published another item about Katriuk the next day, on 30 May 2015. The article conveyed exactly the same information as the story in Vzglyad mentioned above, questioning whether Katriuk had in fact died (Rud' 2015a). Rud' used very negative language in his story, claiming that he did not want Katriuk to rest in peace. ${ }^{13}$ The author also mentioned that in the 1990 s, Katriuk had become

${ }^{12}$ Note that public spaces in today's Belarus use the Soviet name for the war, the 'Great Patriotic War', which encompasses the period of $1941-45$. Belarusian scholars use both designations: 'World War II' when they refer to the period 1939 - 45 or about the military operations of the allied forces outside of the Soviet Union, and the 'Great Patriotic War' when they refer to Germany's attack on the Soviet Union as the starting point, including the period of the Nazi occupation of Belarus (A. Katljarchuk, 'World War II Memory Politics: Jewish, Polish and Roma Minorities of Belarus', The Journal of Belarusian Studies 2013:1, p. 9 - 10).

${ }^{13}$ A translation of the Russian idiom pokoitsia z mirom/mir chyemu-libo prakhu. 
an honourable citizen of Chernivtsi, thus demonstrating the connection between the Canadian government and contemporary Ukraine. According to Per Anders Rudling, Katriuk's honourable citizenship of Chernivtsi was only true according to some sources (Rudling 2012, p. 42).

On 5 June 2015, Narodnaja Hazieta published a letter from a reader named Valerii Lomako entitled 'Irregular Bees' (Lomako 2015). In the letter, the author called Western democracy 'a strange woman', characterizing it as 'biased, evil and with a bad memory' (Lomako 2015). Lomako also accused foreign countries of trying 'to open our eyes to see their version of the truth about the war' (Lomako 2015), thus conflating Katriuk's case and the issue of his extradition with a constructed negative image of democracy overall, one of the most notorious forms of anti-Western propaganda.

On 12 June 2015, the second largest state-owned newspaper, Respublika published a feature by Dmitrii Zhukov and Ivan Kovtun on the Chatyń tragedy. In the article, the authors discussed in detail the history of Schutzmannschaft Bataillon 118, the Soviet-era trials against members of the squad, and the life of Katriuk (Zhukov and Kovtun 2015). The data cited in the article were similar to those quoted in the abovementioned Russian web-sites, focusing on Canada's refusal to extradite Vladimir Katriuk. It also claimed that this decision was linked with the West's deteriorating relations with Russia due to the conflict in Ukraine. ${ }^{14}$ Remarkably, journalists used the word "chekisty," ${ }^{15}$ which continued to carry a derogative connotation long after the collapse of the USSR. However, in this case there authors were stressing the professionalism and hard work of the 'chekisty' in their investigation of Nazi war criminals and portrayed them in a positive light (Zhukov and Kovtun 2015). At the end of the article, the authors mentioned the active participation of Katriuk in the activities of the Ukrainian Orthodox Church in Canada and the fact that he had been designated an honourable citizen of Chernivtsi.

On 19 June 2015 another affiliated newspaper of Belarus Segodnia-Sovetskaia Belorussiia, Selskaia Gazeta Belorusskaia Niva published an article by Yuliia Bolshakova entitled "“Freedom" of Speech for the sake of Nazism is a Crime' (in Russian - "Svobodnoie" slovo v polzu natsizma prestupno') (Bolshakova 2015). This was the most aggressive article to date published on Katriuk by the Belarus Segodnia-Sovetskaia Belorussiia group of newspapers. The author raised the issue of the death of Katriuk and the 'problems' of the global community. Bolshakova called Katriuk 'a threefold scum' and came to the conclusion that 'a society which

\footnotetext{
${ }^{14} \mathrm{NB}$ : This was related to the strong Ukrainian lobby present in Canada on the official level in state institutions.

15 Whether these were NKVD or KGB employees depends on the year, as the name of the body changed several times during the Soviet era. They were initially called chekisty, from the abbreviation for the Emergency Committee in Russian $(C h K)$, the first iteration of the Soviet security police. This term became a common nickname and is still used officially in Belarus.
} 
ignores Nazism can only expect problems like terrorism' (Bolshakova 2015). The author concluded the article with some 'facts' about the threat Belarus is facing from 'weapons, ammunition and drugs' from Ukraine, and the build-up of NATO forces 'on the border with the EU' (Bolshakova 2015).

Another article about Katriuk's death in the state newspaper Zviazda was translated from the Russian news site newsru.com. It adopted a neutral stance, despite mentioning his Ukrainian nationality in the title of the article (Zviazda 2015), which other neutral publications avoided. Three more articles about the death of Vladimir Katriuk in Komsomolskaia Pravda v Belarusi (Savicheva 2015), kyky.org (Kyky.org 2015), and Savvy.by (Savvy.by 2015) were short, neutral, and only stated that he had died and that the Russian Committee of Inquiry had initiated a criminal case against him (Savvy.by 2015) All three sources used the word 'accused' in the titles of their articles, in contrast to articles by pro-governmental sources which called Katriuk 'a butcher' or 'a murderer.'

On 23 June 2016, yet another state-run regional newspaper, Naš Čas Volkovysskaia rayonnaia gazeta, published an article about Vladimir Katriuk. Nadezhda Zinina, the author, wrote about Russia's extradition request and Canada's refusal to comply (Zinina 2015). Zinina also briefly summarized the history of the Schutzmannschaft Bataillon 118, accusing the Canadian government of responding improperly to the genocide of the Slavs and accusing other Western 'democracies' (quotation marks are Zinina's) of having a similar attitude (Zinina 2015). Even though the article was published quite recently, it was not accessible on the newspaper's webpage, only on the webpage's cache. The fact of its unexplained removal is evidence of how easy it is for state mass-media in Belarus to change the content of their websites in order to propagate state-sanctioned views.

All of the main democratically leaning mass-media outlets: Naša Niva (Naša Niva 2015), Charter97 (Charter 97 2015), Radyjo Racyja (Radyjo Racyja 2015), European Radio for Belarus (European Radio for Belarus 2015), and the Belarusian Service of the Polish Radio for Abroad (Polskie Radio dla Zagranicy 2015) published short articles about the death of Vladimir Katriuk in May 28 - 29, 2015. Every article stated that Katriuk was only accused of these crimes and that Russia had requested his extradition. This choice of words contrasted to Belarusian state and Russian media's rhetoric, which presented Katriuk as a murderer. However, European Radio for Belarus did mention his Ukrainian origin and also provided a link to the Declassified History: Chatyn's Butchers documentary discussed above.

Compared with the case of Andrei Sawoniuk, the case of Vladimir Katriuk has garnered much more attention in both the Belarusian and Russian massmedia. However, whereas the rhetoric of the media groupings labelled 'neutral' or oppositional did not vary greatly until his death, pro-state media tended to 
get progressively more negative and sometimes openly aggressive towards their subject. Even the death of Katriuk did not soften their language. The story of Katriuk was also gaining increased circulation since the beginning of the RussianUkrainian conflict in 2013 and reached its culmination when the man died in May 2015, two weeks after Russia filed an extradition request.

\section{Conclusion}

Comparing Internet mass-media discourse surrounding two war criminals, Anthony (Andrei) Sawoniuk and Vladimir Katriuk, reveals several main trends. Obviously, the Belarusian Internet media space did not devote as much attention to the first case as it did to the second. However, both stories remained incomplete. The following reasons can explain the differences in the coverage of the two cases.

Firstly, in order to properly investigate Nazi war crimes on Belarusian territory, the involvement of the Belarusian authorities is absolutely necessary. Scholars and members of the general public seeking facts find it difficult to access potentially helpful archives due to the inaccessible and non-transparent nature of the Belarusian KGB. The Belarusian state is very tight-lipped when it comes to both foreign and local researchers, especially with regards to sensitive issues. For this reason, many Nazi war criminals were discovered only after the end of the Cold War when the necessary files were made available to Western states. Generally speaking, this lack of accessible information during the Cold War period often critically delayed prosecutions of World War II war criminals in different parts of the world. ${ }^{16}$

Secondly, the Soviet regime was reluctant to highlight the divisions between various national and ethnic groups in the Soviet Union after World War II. The Soviet government were especially unlikely to admit that Jews had faced a much greater threat during the war than the Soviet population in general. As the official Belarusian discourse on World War II borrows heavily from the Soviet approach to the issue, the Holocaust remains of secondary importance compared with discussion of the losses of the Belarusian people during the war. Therefore, the crimes of Anthony Sawoniuk, which were committed mainly against Jews, lacked relevance for the official discourse. In contrast, information about Vladimir Katriuk and his involvement in the Chatyn massacre provoked a much greater reaction in the Belarusian media, and various publications began actively disseminating information. The importance of the Chatyń massacre as a symbol for the tragedy of the Belarusian people in World War II in contemporary state ideology was a

\footnotetext{
${ }^{16}$ See S. Wilson, "War Criminals in the Post-war World: the Case of Kato Tetsutaro," p. 109, War in History, 2015. Vol. 22 (1), pp. 87 - 110; L. Douglas, The Right Wrong Man: John Demjanjuk and the Last Great Nazi War Crimes Trial, Princeton University Press, 2016, 352 p.; K. von Lingen, Holmsselring's Last Battle: War Crimes Trials and Cold War Politics 1945 - 1960, Lawrence, KS: University Press of Kansas, 2009, 457 p.
} 
determining factor for media coverage of Valdimir Katriuk, who was allegedly part of the battalion responsible for the massacre. Meanwhile, the participation of Katriuk's battalion in aktions against the Jews was neglected due to the fact that Belarusian suffering overshadowed the Holocaust in Belarusian official discourse.

Thirdly, the year 1999, when the trial against Sawoniuk took place, was a very important time in the contemporary history of Belarus. In that year several political opponents of the Belarusian President disappeared and have not been found since; many people were demanding fair presidential elections and Belarus had entered the Union State of Belarus and Russia, which people feared might lead to the loss of the country's independence. These events became crucial for the further consolidation of the Belarusian regime, and neither the authorities nor the general population could be bothered by a trial taking place in the United Kingdom to investigate the murders of the Jewish population of a small town in Brest region during World War II. The internal and external political situation also played a huge role in the emergence of discussion of Vladimir Katriuk's crimes in 2013-2015. Discussions of war criminals would become important to the Belarusian public only under certain political circumstances.

Moreover, technological progress and the rapid proliferation of the world wide web led to better coverage of the Katriuk case, which occurred in an environment of greater internet connectivity. The fact that both the number of Internet users and on-line sources have substantially increased since 1999 also partially explains why much more information was released about Vladimir Katriuk than Anthony Sawoniuk.

In conclusion, the apathy of contemporary Belarusian authorities towards alternative narratives of the 'glorious' Great Patriotic War, the intensive indoctrination of the Soviet era, and the lack of opportunities to raise awareness of the Holocaust in the present political context make bringing the Holocaust to the fore of Belarusian public discourse highly unlikely. Even though information is becoming more widely available, the chances of Nazi war criminals being discovered (many of whom are now dead of natural causes) remain minimal at present. However, it is indisputable that researchers investigating the crimes of those who participated in the execution of the Belarusian population also had to deal with the Holocaust; they played a valuable role in identifying such criminals while seeking justice for those responsible for one of the cruellest genocides in human history.

In analysing materials on the Belarusian Internet about Sawoniuk and Katriuk several trends emerged. First of all, it is clear that the Russian and Belarusian information spaces overlap greatly, especially with regards to state-owned publications. Not only the sources and information, but also the language and 
semantics used by Belarusian pro-government journalists are very similar to those utilized by their Russian counterparts.

Secondly, as a result of this above-mentioned overlap, Russian propaganda has a profound influence on the Belarusian mass-media and Belarusian propaganda. Very often the texts of Belarusian official mass-media closely echo their Russian analogues. Moreover, even Russian external and internal politics provoke certain topics in the Belarusian state-owned media. This is not the case for 'neutral' or opposition newspapers, which usually try to remain objective or even oppose the messages of Russian mass-media.

Thirdly, the heroes and 'butchers' of the Great Patriotic War will remain a hot topic in Belarusian mass-media as long as the Great Patriotic War remains a central component of the contemporary propaganda of the Belarusian state. As such an approach is also gradually becoming more popular in Russia, Belarus's main strategic partner, the Great Patriotic War will undoubtedly continue to be treated as 'glorious' in the foreseeable future, depending on how long the Belarusian and Russian presidents remain in power.

\section{Bibliography}

\section{Published sources}

Baltacheva, M., Neroznikova, Ye., 2015. Soobschenie o smerti 'khatynskogo palacha' vyglyadit somnitelnym, Vzgliad. Available at: <http://www.vz.ru/ politics/2015/5/29/747997.html>. [Accessed 06 July 2015].

BBC (1999a). UK. Sawoniuk - a hidden life exposed. 1 April 1999. Available at: $<$ http://news.bbc.co.uk/2/hi/uk_news/309937.stm >. [Accessed on 7 April 2015].

BBC (1999b). UK. Sawoniuk jail term dispute. 24 June 1999. Available at: $<$ http://news.bbc.co.uk/2/hi/uk_news/376803.stm >. [Accessed on 7 April 2015].

Belaruspartisan, 2012. U Kanadzie adšukany padazravajemy u datyčanašci da spaĺvannia Chatyni. Available at: <http://www.belaruspartisan.org/bel/ life/210099/>. [Accessed 02 February 2015].

Bolshakova, Yu., 2015. 'Svobodnoie' slovo v polzu natsizma prestupno, Belorusskaia Niva. Available at: <http://belniva.sb.by/obshchestvo-4/article/ svobodnoe-slovo-v-polzu-natsizma-prestupno.html>. [Accessed 06 July 2015]. 
Charter 97, 2015. Abvinavačany u zabojstvach žycharoú Chatyni pamior u Kanadzie. Available at: < http://charter97.org/be/news/2015/5/29/153407/>. [Accessed 05 July 2015].

Chatyń Memorial Complex, 2005. Trahiedyja Chatyni. Available at: $<\mathrm{http}: / /$ www.khatyn.by/by/tragedy/>. [Accessed 01 February 2015].

Dalidovič, J., and Marozava, S., 2013. Kryvavy slied Chatynskich kataŭ, Zviazda, 18 October 2013. Available at: <http://zviazda.by/2013/10/19149.html>. [Accessed 02 February 2015].

Datsyk, V.V., 2006. A. Savoniuk, Domachevo.com. Available at: <http:// domachevo.com/historu-news-ru.htm>. [Accessed 02 February 2015].

Dykhovichnaia, O., and Moloslavov, A., 2008. Pozornaia taina Khatyni, Super Reality. Youtube.com. Available at: <https:/www.youtube.com/ watch?v=px6r9XgT2q0>. [Accessed 05 April 2016].

European Radio for Belarus, 2015. U Kanadzie pamior abvinavačany pa spravie spaliennia bielaruskaj vioski Chatyń. Available at: $<$ http://euroradio.fm/ukanadze-pamyor-abvinavachany-pa-sprave-spalennya-belaruskay-vyoski-hatyn>. [Accessed 06 July 2015].

European Radio for Belarus, 2012. U Kanadzie znajšli adnaho z 'chatynskich kataŭ'. Available at: <http://euroradio.fm/report/u-kanadze-znaishli-adnago-zkhatynskikh-kataw-106113 >. [Accessed 01 February 2015].

Holubieŭ, V., 1999. Vneshniaia politika respubliki Belarus. Fevral’ 1999 goda, Hrights.ru. Available at: <http://www.hrights.ru/text/belorus/b11/Chapter3.htm>. [Accessed 02 February 2015].

Kalinoŭski, V. 1999. Old Bailey sudzić Antona Savaniuka, Naša Niva, 04 (125). Available at: $<$ http://nn.by/?c=ar\&i=93302>. [Accessed 02 February 2015].

Kirkievič, A., 2014. Chatyń: chto spaliŭ bielaruskuju viosku, Novy čas, 16 February 2014. Available at: <http://novychas.info/poviaz_casou/chatynj_ zorstkaje_recha_histor/>. [Accessed 02 February 2015].

Kobiak, R., 1999. Bez sroka davnosti, Vechernii Minsk, 16 February 1999. Available at: <http://www.vminsk.by/news/30/11923/>. [Accessed 02 February 2015].

Kovtun, I., and Zhukov, D., 2015. Krovavye dela khatynskikh palachei, Respublika, 12 June 2015. Available at: <http://respublika.sb.by/obshchestvo-27/ article/krovavye-dela-khatynskikh-palachey.html > . [Accessed 06 July 2015].

Krapivin, S., 2005. Otdal dushu dyavolu Anton Savoniuk, Sovetskaia Belorussiia, 9 November 2005. Available at: <http://tv.sb.by/obshchestvo/article/ otdal-dushu-dyavolu-anton-savonyuk.html $>$. [Accessed 01 February 2015]. 
Kuzovenkov, M., 2014. Rassekrechennaia istoriia. Palachi Khatyni. Bez sroka davnosti, Tvkultura.ru, Telekompaniia 'Pod zankom Pi'. Available at: <https:// www.youtube.com/watch?t=32\&v=B1TOVqukYQc $>$. [Accessed 06 July 2015].

Kyky.org, 2015. Obviniaemyi v ubiistvakh zhitelei Khatyni Vladimir Katriuk umer $v$ Kanade, 29 May 2015. Available at: <http://kyky.org/news/obvinyaemyyv-ubiystvah-zhiteley-hatyni-vladimir-katryuk-umer-v-kanade>. [Accessed 06 July 2015].

Lashkevich, K., 2010. Poslednii 'belorusskii' natsist dozhivaet v Estonii?, Tut.by, 26 August 2010. Available at: <http://news.tut.by/society/195137.html>. [Accessed 02 February 2015].

Lomako, V., 2015. Nepravilnye pchely, Narodnaja Hazieta, 05 May 2015. Available at: $<$ http://ng.sb.by/stati/article/nepravilnye-pchely43.html $>$. [Accessed 06 July 2015].

Maksimov, S. S., 1979. Istoriia odnogo predatelstva, Neotvratimoie vozmezdiie: Po materialam sudebnykh protsessov nad izmennikami Rodiny, fashistkimi palachami i agentami imperialisticheskich razvedok, Moskva, 294 p. Voiennaia literatura. Available at: <http://militera.lib.ru/h/sb_neotvratimoe_vozmezdie/12. html>. [Accessed 06 March 2016].

Moskalenko, G., 2015. Tragediia 'vohniennych viosak', Narodnaja Hazieta, 06 May 2015. Available at: <http://ng.sb.by/stati/article/tragediya-vognennykhvyesak.html>. [Accessed 06 July 2015].

Naviny, 2012. V Kanade nashli odnogo iz palachei Khatyni? Available at: $\quad<$ http://naviny.by/rubrics/society/2012/04/27/ic_articles_116_177672/>. [Accessed 01 February 2015].

Naša Niva, 2012. U Kanadzie adšukany padazravany u datyčanaści da spalvannia Chatyni. Available at: $<$ http://nn.by/?c=ar\&i=72602>. [Accessed 02 February 2015].

NašaNiva, 2015. UKanadziepamior 93-hadovyUladzimir Katruk, abvinavačany pa spravie spaliennia Chatyni. Available at: < http://nn.by/?c=ar\&i=150383 >. [Accessed 05 July 2015].

Nosov, Ye., 2015. SK RF vozbudil ugolovnoie delo v otnoshenii 93-letnego uchatnika ubiistv v Khatyni, Sovetskaia Belorussiia, 10 May 2015. Available at: $<$ http://www.sb.by/v-belarusi/article/sk-rf-vozbudil-ugolovnoe-dela-v-otnoshenii93-letnego-uchastnika-ubiystv-v-khatyni.html>. [Accessed 06 July 2015].

NTV, 2012. Prestarelyi pchelovod okazalsia massovym ubiitsei. Available at: $<$ http://www.ntv.ru/novosti/293479/>. [Accessed 02 February 2015]. 
Polskie Radio dla Zagranicy, 2015. U Kanadzie pamior abvinavačany $\breve{u}$ datyčanaści da zabojstvaŭ u Chatyni. Available at: < http://tinyurl.com/hx3txqg >. [Accessed 06 July 2015].

Radyjo Racyja, 2015. U Kanadzie pamior abvinavačany $\breve{u}$ zabojstvach žycharoŭ Chatyni. Available at: <http://www.racyja.com/hramadstva/u-kanadzepamyor-abvinavachany-u-zabojs/>. [Accessed 05 July 2015].

Rassekrechennaia istoriia, 2014. Tvkultura.ru, Telekompaniia 'Pod zankom $P i$. Available at: <http://tvkultura.ru/video/show/brand_id/31793/episode_ $\mathrm{id} / 993367 />$. [Accessed 06 July 2015].

Respublika, 2012. Ulei dla palacha Khatyni. Available at: <http://tinyurl.com/ jesdene $>$. [Accessed 02 February 2015].

Rinaeva, I., 2015. Pochemu karatel' Khatyni Katriuk schastlivo prozhil v Kanade do 93 let, $M K$, 29 May 2015. Available at: <http://www.mk.ru/social/2015/05/29/ karatel-khatyni-katryuk-skonchalsya-v-kanade-beznakazannym.html>. [Accessed 06 July 2015].

Rud', R., 2015a. Ne pozhelaiu mira ego prakhu, Sovetskaia Belorussiia, 101, 30 May 2015. Available at: <http://www.sb.by/obshchestvo/article/ne-pozhelayumira-ego-prakhu.html>. [Accessed 06 July 2015].

Rud', R., 2015b. On zheg Khatyn, a seichas blagodenstvuiet v Kanade, Sovetskaia Belorussiia, 100, 29 May 2015. Available at: <http://www.sb.by/ obshchestvo/article/on-zheg-khatyn-a-seychas-blagodenstvuet-v-kanade.html>. [Accessed 06 July 2015].

Savicheva, A., 2015. V Kanade skonchalsia Vladimir Katriuk, obvinyaemyi v ubiistvakh v Khatyni, Komsomolskaia Pravda v Belarusi. Available at: <http:// www.kp.by/online/news/2069099>. [Accessed 06 July 2015].

Savvy.by, 2015. V vozraste 93 let skonchalsia obvinyaemyi v khatynskikh ubiistvakh Vladimir Katriuk. Available at: < http://www.savvy.by/novosti/politika/ evropa/item/2984-chatjn.html>. [Accessed 06 July 2015].

Sil'nye novosti, 2012. V Kanade obnaruzhili ukrainskogo politsaia prichastnogo k sozhzheniiu Khatyni. Available at: < http://odsgomel.org/rus/news/ belarus/23377/>. [Accessed 01 February 2015].

Svaboda, 2005. Viadomy bielaruski palicaj pamior u brytanskaj turmie. Available at: <http://www.svaboda.org/content/article/802247.html>. [Accessed 01 February 2015].

Svetlako, A., 2009. Vladimir Katriuk - ot palacha do pasechnika, Livejournal. Available at: <http://svetlako.livejournal.com/29501.html $>$. [Accessed 06 July 2015]. 
Svoboda, 2015. Umer podozrevayemyi $v$ voiennykh prestupleniiakh Vladimir Katriuk. Available at: <http://www.svoboda.org/content/article/27042800.html>. [Accessed 06 July 2015].

Subbotin, I., 2015. Kanada otkazalas' vydat' Rossii obvinyaemogo v genotside v Khatyni Katriuka, MK, 27 May 2015. Available at: <http://www.mk.ru/ social/2015/05/27/kanada-otkazalas-vydat-rossii-obvinyaemogo-v-genocide-vkhatyni-katryuka.html >. [Accessed 06 July 2015].

Supruniuk, A., 1999. Naviny 19 liutaha 1999 hoda, Svaboda.org. Available at: <http:// www.svaboda.org/content/article/24829574.html>. [Accessed 02 February 2015].

The Guardian, 2005. Nazi war criminal Sawoniuk dies in jail. 7 November 2005. Available at: <https://www.theguardian.com/uk/2005/nov/07/secondworldwar. world $>$. [Accessed 05 October 2016].

Tu Thanh Ha, 2015. Alleged Nazi war criminal died two weeks after Russia sought extradition, The Globe and Mail. Available at: <http://www.theglobeandmail.com/ news/national/vladimir-katriuk-died-two-weeks-after-russia-sought-extradition/ article24707200/ >. [Accessed 06 July 2015].

Udf.by, 2012. V Kanade naiden podozrevaemyi v prichastnosti $k$ sozhzheniiu $v$ Khatyni. Available at: <http://udf.by/news/society/58920-v-kanade-naydenpodozrevaemyy-v-prichastnosti-k-sozhzheniyu-hatyni.html>. [Accessed 01 February 2015].

Vesti, 2015. Ubiitsa zhitelei Khatyni Vladimir Katriuk skonchalsia v Kanade. Available at: $<$ http://www.vesti.ru/doc.html?id=2615696>. [Accessed 06 July 2015].

Zinina, N., 2015. Vladimir Katriuk - poslednii karatel' Khatyni, Naš Čas. Available at: $<$ http://tinyurl.com/jcgbflt $>$. [Accessed 06 July 2015].

Zviazda, 2015. U Kanadzie pamior ukrainiec Uladzimir Katruk, jakoha u Rasii sabralisia sudzić za zabojstva žycharoŭ Chatyni. Available at: <http://zviazda. by/2015/05/85507.html>. [Accessed 06 July 2015].

\section{Secondary literature}

Applebaum, A., 1999. The Nightmarish World That Awaits a British Jury, The Sunday Telegraph, February 14, issue 1966, 35.

Canada (Minister of Citizenship and Immigration) v. Katriuk, 1999. Will Zuzak web-site. Available at: <http://www.telusplanet.net/public/mozuz/katriuk/ katriuk991130.html\#bottom3.2>. [Accessed 05 April 2016]. 
Dean, M., 2010. Crime and Comprehension, Punishment and Legal Attitudes. German and Local Perpetrators in Domachevo, Belarus, in the Records of Soviet, Polish, German, and British War Crimes Investigations, p. 265-280, Holocaust and Justice. Representation and Historiography of the Holocaust in Post-War Trials, ed. David Bankier, Dan Michman. Jerusalem: Yad Vashem; New York: Berghahn Books.

Douglas, L., 2016. The Right Wrong Man: John Demjanjuk and the Last Great Nazi War Crimes Trial, Princeton University Press, 352 p.

Encyklapiedyia historyi Bielarusi. U 6 tamach, 1994. Tom 2. Belick - Himn / Redkal.: B. I. Sačanka [i inš.], Minsk: BelEn., 537 p.; il. Karty.

Evreiskaia obschina v Resublike Belarus', 2004. Istoriia yevreyev Belarusi. Available at: $\quad<$ http://www.jewishbelarus.org/index.php?pid=23\&lang=ru $>$. [Accessed 01 February 2015].

Gerlach, C., 1999. Kalkurierte Morde: Die deutsche Wirtschafts- und Vernichtungspolitik in Weißrußland 1941 bis 1944, Hamburger Edition, 1999, 1234 p.

Katljarchuk, A., 2013. World War II Memory Politics: Jewish, Polish and Roma Minorities of Belarus, The Journal of Belarusian Studies, pp. 7-37.

Lingen, K. von, 2009. Kesselring's Last Battle: War Crimes Trials and Cold War Politics, 1945-1960, Lawrence, KS: University Press of Kansas, 457 p.

Marples, D. R., 2014. 'Our Glorious Past': Lukashenka's Belarus and the Great Patriotic War, Stuttgart: Ibidem Verlag, 403 p.

Rudling, P. A., 2013a. The Invisible Genocide: the Holocaust in Belarus, in Bringing the Dark Past to Light, eds. J. - P. Himka and J. B. Michlic, University of Nebraska Press, pp. 59-82.

Rudling, P. A., 2012. The Khatyn Massacre in Belorussia: a Historical Controversy Revisited, Holocaust and Genocide Studies, 26, no. 1 (Spring), pp. 29-58.

Rudling, P. A., 2011. Terror and Local Collaboration in Occupied Belarus: the Case of the Schutzmannschaft Batallion 118. I. Background, Historical Yearbook, vol. VIII, Romanian Academy, "Nicolae Iorga" History Institute, Bucharest, pp. 195-214.

Rudling, P. A., 2013b. Nieprykmietny hienacyd: Chalakost u Bielarusi, ARCHE, 2, July, pp. 120-139.

Vsesoiuznaia perepis' naseleniia, 1939. Natsional'nyi sostav naseleniia po respublikam SSSR. Demoskop Weekly. Available at: < http://demoscope.ru/weekly/ ssp/sng_nac_39.php?reg=3 >. [Accessed 20 April 2016]. 
Vsesoiuznaia perepis' naseleniia, 1959. Natsional'nyi sostav naseleniya po respublikam SSSR. Demoskop Weekly. Available at: <http://demoscope.ru/weekly/ ssp/sng_nac_59.php?reg=3 >. [Accessed 20 April 2016].

Wiesenthal Center Annual Report, 2013. Wiesenthal Center. Available at: $<$ http:// www.wiesenthal.com/atf/cf/\%7B54d385e6-f1b9-4e9f-8e94-890c3e6dd277\%7D/ NAZI-WAR-CRIMINALS-REPORT_2013.PDF>. [Accessed 01 February 2015].

Wiesenthal Center Annual Report, 2014. Wiesenthal Center. Available at: $<$ http:// www.wiesenthal.com/atf/cf/\%7B54d385e6-f1b9-4e9f-8e94-890c3e6dd277\%7D/ WIESENTHAL-CENTER_2014-ANNUAL-NAZI-WAR-CRIMNAL-REPORTV.2.PDF $>$. [Accessed 01 February 2015].

Wilson, S., 2015. War Criminals in the Post-War World: the Case of Kato Tetsutaro, War in History, Vol. 22 (1), pp. 87-110. 